\title{
Immunoglobulin-like transcript 4 and human leukocyte antigen-G interaction promotes the progression of human colorectal cancer
}

\author{
ZHAOYANG CAI ${ }^{1}$, LU WANG $^{2}$, YALI HAN ${ }^{3}$, WENWEN GAO ${ }^{2}$, XIAOJUAN WEI $^{4}$, \\ RUMEI GONG ${ }^{4}$, MINGLIANG ZHU ${ }^{1}$, YUPING SUN ${ }^{4}$ and SHUWEN YU ${ }^{1,2}$ \\ ${ }^{1}$ School of Pharmaceutical Sciences, Shandong University, Jinan, Shandong 250012; \\ ${ }^{2}$ Department of Pharmacy, Jinan Central Hospital Affiliated to Shandong University, Jinan, Shandong 250013; \\ ${ }^{3}$ Department of Radiation Oncology, Qilu Hospital of Shan-dong University, Jinan, Shandong 250012; ${ }^{4}$ Department of \\ Oncology, Jinan Central Hospital Affiliated to Shandong University, Jinan, Shandong 250013, P.R. China
}

Received September 11, 2018; Accepted February 11, 2019

DOI: $10.3892 /$ ijo.2019.4761

\begin{abstract}
Immunoglobulin-like transcript (ILT) 4, a negative regulator of immune response in allograft rejection, autoimmunity and infectious diseases, has recently been determined to serveimportant roles in tumor development.In the present study, the co-expression of ILT4 and human leukocyte antigen-G (HLA-G) in tissues of human primary colorectal cancer (CRC) was revealed, and its association with older age, advanced stage, regional lymph node involvement and poor overall survival time was identified. In CRC cell lines, ILT4 and HLA-G co-expression and their autocrine regulation was demonstrated. ILT4 interference affected HLA-G expression and regulated the cell proliferation, invasion and migration of CRC. HLA-G fusion protein treatment also increased ILT4 expression in a dose-dependent manner, thereby activating protein kinase B (AKT) and extracellular signal-regulated kinase (ERK) signaling, and facilitating the proliferation, migration and invasion of CRC cells. Additionally, the AKT and ERK activation, and CRC cell malignant characteristics
\end{abstract}

Correspondence to: Professor Shuwen Yu, School of Pharmaceutical Sciences, Shandong University, 44 Wenhua Xi Road, Jinan, Shandong 250012, P.R. China

E-mail: yaoxuebu2012@163.com

Professor Yuping Sun, Department of Oncology, Jinan Central Hospital Affiliated to Shandong University, 105 Jie Fang Road, Jinan, Shandong 250013, P.R. China

E-mail: 13370582181@163.com

Abbreviations: CRC, colorectal cancer; HLA-G, human leukocyte antigen-G; ILT4, immunoglobulin-like transcript 4; AKT, protein kinase B; ERK, extracellular signal-regulated kinase; DC, dendritic cell; MHC, major histocompatibility complex; SHP, protein tyrosine phosphatase; NSCLC, non-small cell lung cancer; OS, overall survival; RT-qPCR, reverse transcription-quantitative polymerase chain reaction

Key words: CRC, tumor progression, ILT4, HLA-G, prognostic biomarker induced by HLA-G may be suppressed by blocking ILT4. The present results indicated that the interaction of ILT4 and its ligand HLA-G promotes CRC progression through AKT and ERK signal activation, providing a novel strategy of blocking ILT4/HLA-G for the treatment of CRC.

\section{Introduction}

Colorectal cancer (CRC) is one of the most common malignancy types and the fourth most common cause of tumor-associated mortality globally in 2008 (1). Despite improvements in the diagnosis and treatment of CRC, the efficacy of surgery and chemotherapy remains unsatisfactory, and the 5-year survival rate of patients with CRC with metastasis remains $<10 \%$ in 2012 globally (2-4). Therefore, further investigation on the molecular mechanisms of CRC progression is urgently required, which may help to elucidate novel therapeutic strategies for CRC.

Immunoglobulin-like transcript (ILT) 4 , which is also termed lymphocyte immunoglobulin-like receptor 2, belongs to the ILT family. It is an immune inhibitory receptor expressed in macrophages, monocytes, myeloid and dendritic cells (DCs) $(5,6)$. ILT4 binds to classical [(human leukocyte antigen-A) HLA-A and -B] and non-classical (HLA-G, -E and -F) major histocompatibility complex (MHC) class I molecules, and has been identified to induce inhibitory signaling via immunoreceptor tyrosine-based inhibitory motifs, which is considered to recruit protein tyrosine phosphatase (SHP)-1 or SHP-2 $(7,8)$. Our previous studies determined that ILT4 was aberrantly expressed in breast cancer and non-small cell lung cancer (NSCLC), and its expression was correlated with poor prognosis (9-11). However, the expression of ILT4 has not been investigated in CRC to date.

HLA-G is a non-classical MHC class I molecule with four membrane-bound (HLA-G 1-4) and three soluble (HLA-G 5-7) isoforms (11). Binding with the receptors ILT2 and ILT4, HLA-G serves a crucial role in regulating immune activities (12-14). Additionally, HLA-G expression has been demonstrated to be involved in viral infection, organ transplantation, inflammatory reactions, autoimmune diseases and cancer, primarily serving an immune inhibitory function. 
Up to now, numerous researchers reported that the presence of HLA-G in numerous cancer types, including NSCLC and leukemia, is correlated with poor prognosis (15-17). ILT4/HLA-G has been investigated as an inhibitory axis in simian immunodeficiency virus and human immunodeficiency virus infections, recurrent implantation failure and systemic lupus erythematosus (18-20). In a previous study, the co-expression of ILT4/HLA-G in NSCLC and its correlation with a reduced overall survival (OS) time in patients with NSCLC was revealed, and also its activation of extracellular signal-regulated kinase (ERK) signaling was demonstrated.

The present study investigated the co-expression of ILT4/HLA-G in human CRC tissues, and analyzed the association between ILT4/HLA-G and the clinicopathological characteristics and survival time of patients with CRC. The co-expression of ILT4/HLA-G was detected in CRC cell lines, in addition to its effect on cell proliferation, invasion and migration; furthermore, the potential signaling mechanism of protein kinase $\mathrm{B}$ (AKT) and ERK activation underlying ILT4/HLA-G-induced CRC progression was investigated.

\section{Materials and methods}

Patients. A total of 88 tumor tissues were obtained from patients with CRC who underwent surgery between January 2013 and December 2014 at Jinan Central Hospital Affiliated to Shandong University (Jinan, China). Prior to the surgery, the patients had not received chemotherapy, radiotherapy or immunotherapy. Among the patients, $77.27 \%$ (68/88) were male and $22.73 \%(20 / 88)$ were female. Patients were aged from 20-90 years old with a mean age of 67.17 years. Follow-up data were summarized on April 14th 2018, with a median follow-up time of 60 months. Tumor tissues were classified according to the American Joint Committee on Cancer Cancer Staging Manual (21). The present study was supported by the Institutional Review Boards of Jinan Central Hospital Affiliated to Shandong University, and written informed consent was obtained from all patients.

Immunohistochemistry. Human CRC tissues and adjacent normal tissues were fixed in $10 \%$ formalin (Phygene, Fuzhou, China; cat. no. PH0996) for $24 \mathrm{~h}$ at room temperature. Subsequently, it was dehydrated with different concentrations of ethanol (70, 85, 95 and 100\%) and xylene, embedded in paraffin and cut to a thickness of $4 \mu \mathrm{m}$. When the sections had been de-paraffinized by xylene and rehydrated by different concentrations of ethanol (100, 95 and $75 \%)$, antigen retrieval was performed by heating the specimens in Tris-EDTA buffer (Wuhan Sanying Biotechnology, Wuhan, China; cat. no. B600011) for $10 \mathrm{~min}$ in a microwave oven (Guangdong Galanz Group Co., Ltd., Guangdong, China; P70D20TL-D4) at medium heat. Following naturally cooling the sections, they were incubated in $3 \% \mathrm{H}_{2} \mathrm{O}_{2}$ at room temperature for $10 \mathrm{~min}$ and blocked in $10 \%$ goat serum (OriGene Technologies, Inc., Rockville, MD, USA; cat. no. ZLI-9021) at room temperature for $1 \mathrm{~h}$. The sections were incubated with rabbit polyclonal anti-ILT4 anti-body (1:100; OriGene Technologies, Inc.; cat. no. TA349368) and mouse monoclonal anti-HLA-G antibody (1:200; Abcam, Cambridge, UK; cat. no. ab52455) at $4^{\circ} \mathrm{C}$ overnight, followed by detection with an Elivision Plus Polymer
Table I. Interference sequences of ILT4.

\begin{tabular}{lc}
\hline Name & \multicolumn{1}{c}{ Sequence $\left(5^{\prime}-3^{\prime}\right)$} \\
\hline shILT4 & GAAGAAGAACACCCACAATGC \\
shNC & GTTCTCCGAACGTGTCACGT
\end{tabular}

ILT4, immunoglobulin-like transcript 4; sh, short hairpin; NC, negative control.

Horseradish Peroxidase (mouse/rabbit) IHC kit (25 min) and streptavidin-conjugated peroxidase $(25 \mathrm{~min})$. The sections were visualized using 3,3'-diaminobenzidine solution (Fuzhou Maixin Biotech Co., Ltd., Fuzhou, China) and counterstained with hematoxylin at room temperature. Normal mouse IgG (1:20,000; Abcam; cat. no. ab205719) and rabbit IgG (1:10,000; OriGene Technologies, Inc.; cat. no. 17502-0.2mG) were used instead of the primary antibody as a negative control.

A total of two independent researchers analyzed the immunohistochemistry results. The stained-cell percentages in at least five fields were recorded at x400 magnification under a light microscope (NIKON ECLIPSE TI-SR; Nikon Corporation, Tokyo, Japan). The sections were scored as positive or negative by a previously described method (11).

Cell lines and cell culture. The human colon epithelial cell line FHC was purchased from the American Type Culture Collection (ATCC; Manassas, VA, USA). The HCT1116, HT29, SW480 and SW620 cell lines were obtained from the Institutes of Biochemistry and Cell Biology (Shanghai, China), and originated from the ATCC. All cells were cultured in RPMI-1640 medium (HyClone; GE Healthcare Life Sciences, Logan, UT, USA) containing 10\% fetal bovine serum (FBS; HyClone; GE Healthcare Life Sciences). All cells were cultured in a humidified atmosphere containing $5 \% \mathrm{CO}_{2}$ at $37^{\circ} \mathrm{C}$.

Cell transfection. Downregulation of ILT4 expression was performed by transfecting plasmid pGPU6/GFP/Neo-short hairpin (sh)ILT4-1 (shILT4; Shanghai GenePharma Co., Ltd., Shanghai, China) in to HCT116 and SW620 cells. Non-targeting plasmid [sh-negative control (NC); Shanghai GenePharma Co., Ltd.] was used as a negative control. Plasmid Pez-lv105-ILT4 (ILT4) (GeneCopoeia, Inc., Rockville, MD, USA) was added to HT29 and SW480 cells to upregulate the level of ILT4, plasmid Pez-lv105 (NC; GeneCopoeia, Inc.) was used as negative control. When the cells had reached 40-60\% confluence in 6-well plates, plasmids and X-treme GENE HP reagents (Roche Diagnostics, Basel, Switzerland) were added to the cells at a ratio of $2 \mu \mathrm{g} / 6 \mu \mathrm{g}$ according to the manufacturer's protocols. The level of mRNA were detected by reverse transcription-quantitative polymerase chain reaction (RT-qPCR) after $24 \mathrm{~h}$ and the level of protein was detected by western blot assays after $48 \mathrm{~h}$ following transfection. The interference sequences of ILT4 are listed in Table I. The overexpression sequences of ILT4 are listed in Fig. S1.

Protein extraction and western blotting. Total proteins were extracted from CRC and FHC cells. Following 
Table II. Primers used in reverse transcription-quantitative polymerase chain reaction.

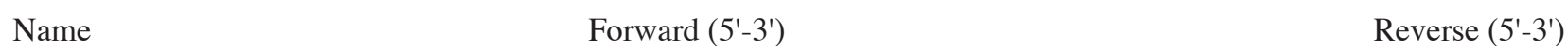

\section{ILT4}

HLA-G

GAPDH

GCATCTTGGATTACACGGAT
GGCAGCCTATGACATTCCCC
AGAAGGCTGGGGCTCATTTG

CTGACAGCCATATCGCCCTG GTCTTGGAGCCTTCTCCCTC AGGGGCCATCCACAGTCTTC

ILT4, immunoglobulin-like transcript 4; HLA-G, human leukocyte antigen-G.

washing in ice-cold PBS for 1 min, cell lysates were lysed in radioimmunoprecipitation assay lysis buffer containing a protease and phosphatase inhibitor cocktail (Thermo Fisher Scientific, Inc., Waltham, MA, USA). Proteins were quantified using a Pierce bicinchoninic acid assay (Thermo Fisher Scientific, Inc.). A mass of $30 \mu \mathrm{g}$ protein/lane was separated via $10 \%$ SDS-PAGE and transferred onto polyvinylidene fluoride (PVDF) membranes (EMD Millipore, Billerica, MA, USA) using semidry transfer apparatus. Following blocking in TBS with $0.1 \%$ Tween-20 and 5\% non-fat milk for $1 \mathrm{~h}$ at room temperature, the PVDF membranes were incubated with mouse monoclonal anti-HLA-G antibody (1:1,000; Abcam; cat. no. ab52455), rabbit polyclonal anti-ILT4 antibody (1:500; Abcam; cat. no. ab128349), rabbit monoclonal anti-phospho-AKT antibody (1:1,000; Cell Signaling Technology, Inc., Danvers, MA, USA; cat. no. 4060), rabbit monoclonal anti-AKT antibody (1:1,000; Epitomics; Abcam; cat.no. 2957-1), rabbit monoclonal anti-phospho-ERK antibody (1:1,000; Abcam; cat. no. ab201015) and rabbit monoclonal anti-ERK antibody (1:1,000; Cell Signaling Technology, Inc.; cat. no. 4695) at $4^{\circ} \mathrm{C}$ overnight. The blots were incubated in horseradish peroxidase-conjugated secondary goat anti-mouse (1:10,000; Wuhan Sanying Biotechnology; cat. no. SA00001-1) or goat anti-rabbit antibodies (1:10,000; Wuhan Sanying Biotechnology; cat. no. SA00001-2) for $1 \mathrm{~h}$ at room temperature. Finally, the blots were developed in Enhanced Chemiluminescence reagent (EMD Millipore) and exposed using a ChemiDoc ${ }^{\mathrm{TM}}$ XRS+ system (Bio-Rad Laboratories, Inc., Hercules, CA, USA). GAPDH (1:10,000; Wuhan Sanying Biotechnology; cat. no. 10494-1-AP) antibody was used as the loading control. Image J 1.8.0 (National Institutes of Health, Bethesda, MD, USA) was employed to quantify protein levels.

RT-qPCR analysis. Total RNA was extracted using TRIzol ${ }^{\circledR}$ reagent (Invitrogen; Thermo Fisher Scientific, Inc.). The cDNAs were synthesized from $2 \mu \mathrm{g}$ total RNA using a Thermo Scientific RevertAid First Strand cDNA Synthesis kit (Thermo Fisher Scientific, Inc.). RT-qPCR was performed using a Fast Start Universal SYBR ${ }^{\circledR}$ Green RT-PCR kit (Roche Diagnostics) and ABI 7500 Fast Real-Time PCR system (Applied Biosystems; Thermo Fisher Scientific, Inc.; $50^{\circ} \mathrm{C}$ for $2 \mathrm{~min}, 95^{\circ} \mathrm{C}$ for $10 \mathrm{~min}$ and $95^{\circ} \mathrm{C}$ for $15 \mathrm{sec}$ for 40 cycles). The forward and reverse primer sequences are listed in Table II. The mRNAs were normalized to GAPDH. The $2^{-\Delta \Delta C q}$ method was used to evaluate the relative expression levels of the genes (22).

Treatment of HLA-G fusion protein and anti-ILT4 blocking antibody. HT29 cells were plated at a concentration of
$1 \times 10^{5}$ cells $/ \mathrm{ml}$ in 6 -well plates, each well containing $2 \mathrm{ml}$ RPMI-1640 medium with 10\% FBS, and cultured at $37^{\circ} \mathrm{C}$. When the cells had reached $60-70 \%$ confluence in 6-well plates, HLA-G fusion protein (Wuhan Sanying Biotechnology; cat. no. Ag10839) at concentrations of 10 , 20, 50, 100, 200 and $500 \mathrm{ng} / \mathrm{ml}$ was added according to the manufacturer's protocols. Each well contained $2 \mathrm{ml}$ RPMI-1640 medium with 10\% FBS. The cells were incubated at $37^{\circ} \mathrm{C}$, and then analyzed at $24 \mathrm{~h}$ with an RT-qPCR assay and at $48 \mathrm{~h}$ by western blotting according to the aforementioned protocols.

HT29 cells were treated with $0.5 \mu \mathrm{g} / \mathrm{ml}$ anti-ILT4 blocking antibody (R\&D Systems, Inc., Minneapolis, MN, USA; cat. no. MAB2078) in 6-well plates at $37^{\circ} \mathrm{C}$, using $0.5 \mu \mathrm{g} / \mathrm{ml} \operatorname{IgG}(\mathrm{R} \& \mathrm{D}$ Systems, Inc.; cat. no. 1-001-A) and PBS as negative controls. After $12 \mathrm{~h}$, cells were treated with $200 \mathrm{ng} / \mathrm{ml}$ HLA-G fusion protein at $37^{\circ} \mathrm{C}$, and after $48 \mathrm{~h}$ the total protein levels were detected by western blotting, according to the aforementioned protocol. The peptide sequence of the HLA-G fusion protein was as follows: SHSMRYFSAAVSRPS RGE PRFIAMGYVD DTQFVRFDSDSACPRMEPRAPWVEREGPEYWEEETRN TKAHAQTDRMNLQTLRGYYNQSEASSHTLQWMIGC DLGSDGRLLRGYEQYAYDGKDYLALNEDLRSWTAAD TAAQISKRKCEAANVAEQRRAYLEGTCVEWLHRYLEN GKEMLQRADPPKTHVTHHPVFDYEATLRCWALGFYP AEIILTWQRDGEDQTQDVELVETKPAGDGTFQKWAAV VVPSGEEQRYTCHVQHEG LPEPLMLRWKQSSLPTIPI (26-308aa encoded by BC021708).

Cell proliferation assay. Cells were plated in 96-well culture plates at a concentration of $3 \times 10^{3}$ cells/well, each well containing $100 \mu \mathrm{l}$ RPMI-1640 medium with $10 \%$ FBS. After incubation for 6, 24, 48, 72 and $96 \mathrm{~h}$ at $37^{\circ} \mathrm{C}$, cells were treated with $10 \mu \mathrm{l}$ Cell Counting Kit-8 (Dojindo Molecular Technologies, Inc., Kumamoto, Japan) solution and incubated at $37^{\circ} \mathrm{C}$ for $4 \mathrm{~h}$, and subsequently measured at $450 \mathrm{~nm}$. All assays were performed at least three times.

Wound-healing assay. CRC cells (HCT1116, HT29, SW480 and SW620) were plated at a concentration of $1 \times 10^{5}$ cells $/ \mathrm{ml}$ in 6-well plates, each well containing $2 \mathrm{ml} \mathrm{RPMI-1640} \mathrm{medium}$ with $10 \% \mathrm{FBS}$, and cultured at $37^{\circ} \mathrm{C}$ for $24 \mathrm{~h}$. Subsequently, the cells were scratched with a sterile $200 \mu \mathrm{l}$ pipette tip. PBS was used to wash the cell debris. Images were acquired at 0 and $24 \mathrm{~h}$ in the same location under a light microscope (Carl Zeiss AG, Oberkochen, Germany; magnification, x40). The scratch wound widths were calculated in three random fields of view. 
Table III. Association between the expression of ILT4 and HLA-G and clinicopathological characteristics in human CRC tissues.

\begin{tabular}{|c|c|c|c|c|c|c|c|c|c|}
\hline \multirow[b]{2}{*}{ Clinical parameters } & \multirow[b]{2}{*}{$\mathrm{N}$} & \multicolumn{2}{|c|}{ ILT4 } & \multirow[b]{2}{*}{$\chi^{2}$} & \multirow[b]{2}{*}{$P 1$} & \multicolumn{2}{|c|}{ HLA-G } & \multirow[b]{2}{*}{$\chi^{2}$} & \multirow[b]{2}{*}{$P 2$} \\
\hline & & + & - & & & + & - & & \\
\hline \multicolumn{10}{|l|}{ Age (year) } \\
\hline$\leq 65$ & 36 & 24 & 12 & 0.064 & 0.800 & 22 & 14 & 0.103 & 0.748 \\
\hline$>65$ & 52 & 36 & 16 & & & 30 & 22 & & \\
\hline \multicolumn{10}{|l|}{ Sex } \\
\hline Male & 68 & 52 & 16 & 9.475 & $0.002^{\mathrm{b}}$ & 42 & 26 & 0.885 & 0.347 \\
\hline Female & 20 & 8 & 12 & & & 10 & 10 & & \\
\hline \multicolumn{10}{|c|}{ Primary tumor localization } \\
\hline Right-sided & 24 & 16 & 8 & 0.040 & 0.980 & 15 & 9 & 0.159 & 0.924 \\
\hline Left-sided & 38 & 26 & 12 & & & 22 & 16 & & \\
\hline Rectum & 26 & 18 & 8 & & & 15 & 11 & & \\
\hline \multicolumn{10}{|l|}{ Tumor size $(\mathrm{cm})$} \\
\hline$\leq 5$ & 52 & 37 & 15 & 0.518 & 0.472 & 33 & 19 & 1.004 & 0.316 \\
\hline$>5$ & 36 & 23 & 13 & & & 19 & 17 & & \\
\hline \multicolumn{10}{|l|}{ Tumor differentiation } \\
\hline Mediate-low/low & 41 & 27 & 14 & 0.192 & 0.661 & 21 & 20 & 1.968 & 0.161 \\
\hline High/mediate & 47 & 33 & 14 & & & 31 & 16 & & \\
\hline \multicolumn{10}{|c|}{ Lymph node metastasis } \\
\hline- & 48 & 26 & 22 & 9.561 & $0.002^{\mathrm{b}}$ & 28 & 20 & 0.025 & 0.874 \\
\hline+ & 40 & 34 & 6 & & & 24 & 16 & & \\
\hline \multicolumn{10}{|l|}{ TNM stage groupings } \\
\hline $\mathrm{I} / \mathrm{II}$ & 44 & 28 & 16 & 0.838 & 0.360 & 21 & 23 & 4.701 & $0.030^{\mathrm{a}}$ \\
\hline III/IV & 44 & 32 & 12 & & & 31 & 13 & & \\
\hline
\end{tabular}

Tumor tissues were classified according to the AJCC Cancer Staging Manual (21). ${ }^{a} \mathrm{P}<0.05$ and ${ }^{\mathrm{b}} \mathrm{P}<0.01$. ILT4, immunoglobulin-like transcript 4 ; HLA-G, human leukocyte antigen G; TNM, tumor node metastasis; P1, P-value for the significance between ILT4+ and ILT4-; P2, P-value for the significance between HLA-G+ and HLA-G-.
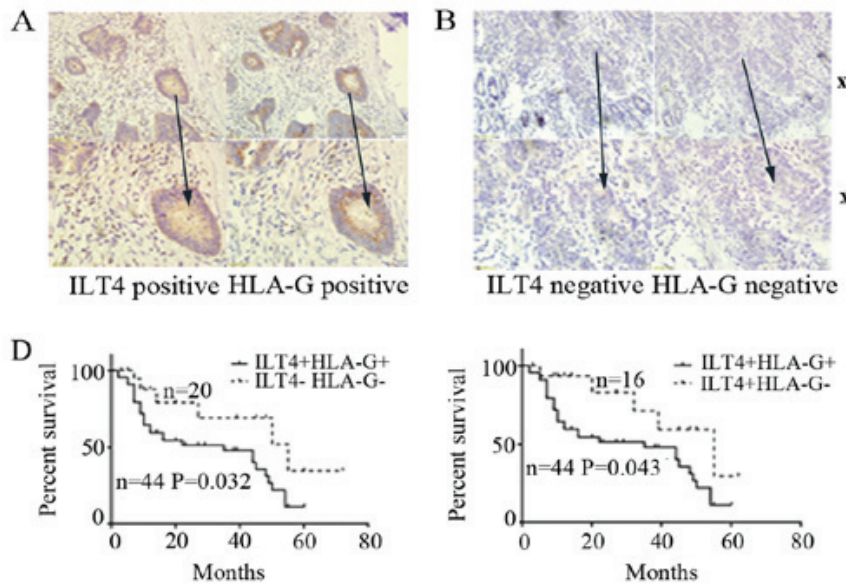
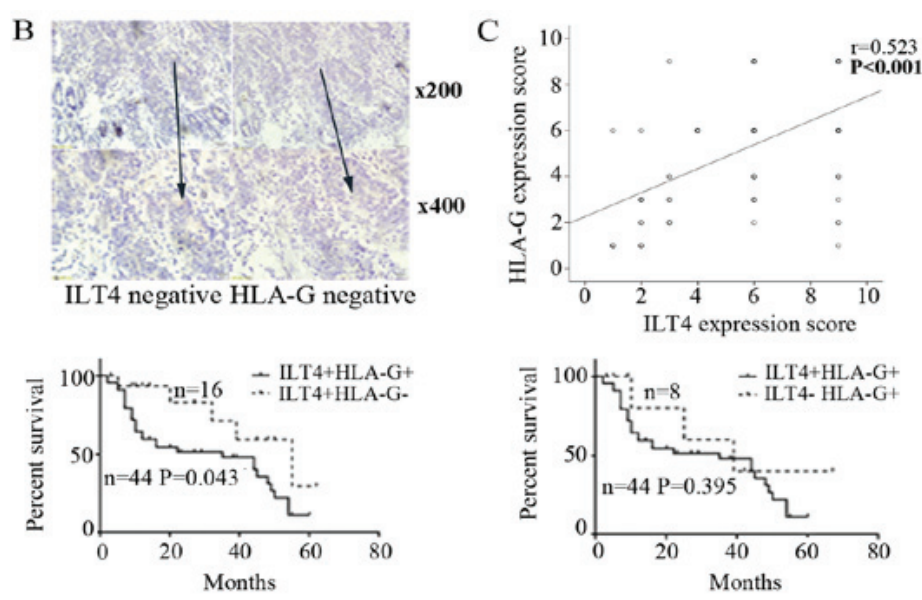

Figure 1. Expression of ILT4 and HLA-G protein in tumor tissues from patients with CRC. (A) The co-expression of ILT4 and HLA-G protein detected in CRC tissues by immunohistochemistry (magnification, x200 and x400). (B) In adjacent normal colorectal tissues, ILT4 and HLA-G expression was too weak to be observed (magnification, x200 and x400). (C) Spearman's correlation analysis revealed that ILT4 expression was positively correlated with HLA-G expression $(\mathrm{n}=88, \mathrm{P}<0.001)$. (D) Overall survival time curves of patients with CRC in the four groups, generated via Kaplan-Meier survival analysis. CRC, colorectal cancer; HLA-G, human leukocyte antigen-G; ILT4, immunoglobulin-like transcript 4.

Transwell migration assay. Cell migration was assessed using Transwell insert chambers with a pore size of $8 \mu \mathrm{m}$ (Corning
Inc., Corning, NY, USA). Approximately $1 \times 10^{5}$ cells in RPMI-1640 without FBS were cultured in the upper chamber. 
Table IV. Association between the co-expression of ILT4/HLA-G and clinicopathological characteristics in human CRC tissues.

\begin{tabular}{|c|c|c|c|c|c|c|c|c|c|c|}
\hline \multirow[b]{2}{*}{ Clinical parameters } & \multirow{2}{*}{$\frac{\text { ILT4+/HLA-G+ }}{\mathrm{N}}$} & \multicolumn{3}{|c|}{ ILT4-/HLA-G- } & \multicolumn{3}{|c|}{ ILT4+/HLA-G- } & \multicolumn{3}{|c|}{ ILT4-/HLA-G+ } \\
\hline & & $\mathrm{n}$ & $\chi^{2}$ & $P 1$ & $\mathrm{n}$ & $\chi^{2}$ & $P 2$ & $\mathrm{n}$ & $\chi^{2}$ & $P 3$ \\
\hline \multicolumn{11}{|l|}{ Age (year) } \\
\hline$\leq 65$ & 16 & 6 & 0.247 & 0.619 & 8 & 0.909 & 0.340 & 6 & 4.140 & $0.042^{\mathrm{a}}$ \\
\hline$>65$ & 28 & 14 & & & 8 & & & 2 & & \\
\hline \multicolumn{11}{|l|}{$\operatorname{Sex}$} \\
\hline Male & 39 & 13 & 5.042 & $0.025^{\mathrm{a}}$ & 13 & 0.554 & 0.457 & 3 & 11.396 & $0.001^{\mathrm{b}}-e^{2}$ \\
\hline Female & 5 & 7 & & & 3 & & & 5 & & \\
\hline \multicolumn{11}{|c|}{ Primary tumor localization } \\
\hline Right-sided & 11 & 4 & 0.283 & 0.868 & 5 & 1.316 & 0.518 & 4 & 4.326 & 0.115 \\
\hline Left-sided & 18 & 8 & & & 8 & & & 4 & & \\
\hline Rectum & 15 & 8 & & & 3 & & & 0 & & \\
\hline \multicolumn{11}{|l|}{ Tumor size $(\mathrm{cm})$} \\
\hline$\leq 5$ & 29 & 11 & 0.698 & 0.403 & 8 & 1.256 & 0.262 & 4 & 0.739 & 0.390 \\
\hline$>5$ & 15 & 9 & & & 8 & & & 4 & & \\
\hline \multicolumn{11}{|l|}{ Tumor differentiation } \\
\hline Mediate-low/low & 17 & 10 & 0.728 & 0.394 & 10 & 2.700 & 0.100 & 4 & 0.363 & 0.547 \\
\hline High/mediate & 27 & 10 & & & 6 & & & 4 & & \\
\hline \multicolumn{11}{|c|}{ Lymph node metastasis } \\
\hline- & 21 & 15 & 4.156 & $0.041^{\mathrm{a}}$ & 5 & 1.297 & 0.255 & 7 & 4.309 & $0.038^{a}$ \\
\hline+ & 23 & 5 & & & 11 & & & 1 & & \\
\hline \multicolumn{11}{|l|}{ TNM stage groupings } \\
\hline $\mathrm{I} / \mathrm{II}$ & 15 & 10 & 1.462 & 0.227 & 13 & 10.484 & $0.001^{\mathrm{b}}$ & 6 & 4.705 & $0.030^{\mathrm{a}}$ \\
\hline III/IV & 29 & 10 & & & 3 & & & 2 & & \\
\hline
\end{tabular}

Tumor tissues were classified according to the AJCC Cancer Staging Manual (21). ${ }^{a} \mathrm{P}<0.05$ and ${ }^{\mathrm{b}} \mathrm{P}<0.01$. TNM tumor node metastasis, ILT4 immunoglobulin-like transcript 4, HLA-G human leukocyte antigen G; P1, P-value for the significance between the ILT4+/HLA-G+ and ILT4-/ HLA-G- groups; P2, P-value for the significance be-tween the ILT4+/HLA-G+ and ILT4+/HLA-G- groups; $P 3$, P-value for the significance between the ILT4+/HLA-G+ and ILT4-/HLA-G+ groups.

RPMI-1640 medium supplemented with 10\% FBS was added to the bottom chamber as a chemoattractant. Subsequently, the cells were incubated at $37^{\circ} \mathrm{C}$ for $24 \mathrm{~h}$. The migrated cells were fixed with $20 \%$ methanol for $20 \mathrm{~min}$ at $37^{\circ} \mathrm{C}$ and stained with $0.1 \%$ crystal violet (Invitrogen; Thermo Fisher Scientific, Inc.) for $15 \mathrm{~min}$ at $37^{\circ} \mathrm{C}$. The number of cells in three fields of each sample was counted under a light microscope (Carl Zeiss AG; magnification, x100). Cell numbers were calculated from five random fields.

Matrigel invasion assay. Cell invasion was determined using Matrigel invasion chambers (BD Biosciences; Becton, Dickinson and Company, Franklin Lakes, NJ, USA). The upper chambers were covered with Matrigel, which was diluted in cold PBS and incubated at $37^{\circ} \mathrm{C}$ for $1 \mathrm{~h}$. Approximately $1 \times 10^{5}$ cells were suspended in RPMI-1640 medium without FBS and transferred into the upper chambers. RPMI-1640 medium supplemented with $10 \%$ FBS was added to the bottom chamber as a chemoattractant. Subsequently, the cells were incubated at $37^{\circ} \mathrm{C}$ for $24 \mathrm{~h}$. The migrated cells were fixed with $20 \%$ methanol for $20 \mathrm{~min}$ at $37^{\circ} \mathrm{C}$ and stained with $0.1 \%$ crystal violet for $15 \mathrm{~min}$ at $37^{\circ} \mathrm{C}$. The number of cells in three fields of each sample was counted under a light microscope (Carl Zeiss
AG; magnification, x100). Cell numbers were calculated from five random fields.

Statistical analysis. All data are presented as the mean \pm standard deviation. SPSS version 18.0 (SPSS, Inc., Chicago, IL, USA) and GraphPad Prism 5 (GraphPad Software, Inc., La Jolla, CA, USA) were selected to perform the statistical analysis. OS curves were generated via the by Kaplan-Meier method and compared by means of the log-rank test. The associations between ILT4, HLA-G and clinicopathological characteristics of patients with CRC were analyzed with the $\chi^{2}$ test. The correlation between ILT4 and HLA-G expression in CRC tissues was analyzed by Spearman's correlation coefficient. The differences in characteristics between two groups were examined by Student's t-test. The differences in characteristics between three or more groups were examined by one-way analysis of variance followed by Tukey's post-hoc test. $\mathrm{P}<0.05$ was considered to indicate a statistically significant difference.

\section{Results}

Co-expression of ILT4 and HLA-G is detected in human CRC tissues. ILT4 and HLA-G positive expression was detected in 

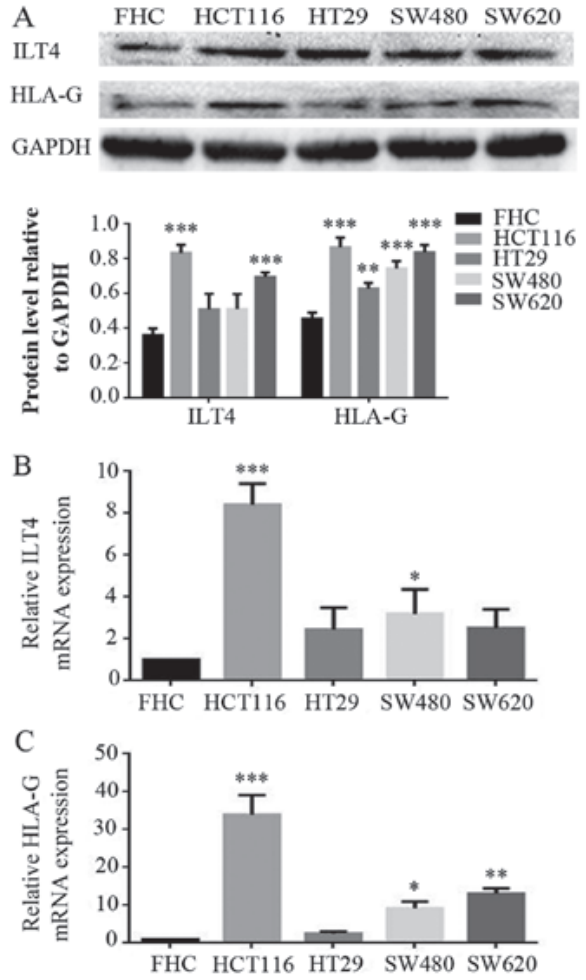

Figure 2. Co-expression of ILT4 and HLA-G in human CRC cells. (A) CRC cells (HCT116, HT29, SW480 and SW620 cells) exhibited increased protein levels of ILT4 and HLA-G expression, compared with normal cells (FHC). (B) CRC cells (HCT116, HT29, SW480 and SW620 cells) exhibited increased mRNA levels of ILT4 expression, compared with normal cells (FHC). (C) CRC cells (HCT116, HT29, SW480 and SW620 cells) exhibited increased mRNA levels of HLA-G expression, compared with normal cells (FHC). GAPDH served as a loading control. The results are presented as the mean \pm standard deviation of three independent experiments. ${ }^{~} \mathrm{P}<0.05$, ${ }^{* * *} \mathrm{P}<0.01$ and ${ }^{* * * *} \mathrm{P}<0.001$ vs. the corresponding expression level of FHC. CRC, colorectal cancer; HLA-G, human leukocyte antigen-G; ILT4, immunoglobulin-like transcript 4.

the cell cytoplasm and in some cancer stromal cells (Fig. 1A). In adjacent normal colorectal tissues, ILT4 and HLA-G expression was too weak to be observed (Fig. 1B). In total, $68.18 \%(60 / 88)$ of the tissue samples exhibited overexpression of ILT4 and 59.09\% (52/88) of the tissue samples exhibited overexpression of HLA-G. There was a notable positive correlation between ILT4 and HLA-G expression, and positive ILT4 expression had an increased probability of being observed in HLA-G-positive tissues, compared with HLA-G-negative tissues $(\mathrm{P}<0.001$; Fig. 1C).

Co-expression levels of ILT4/HLA-G are associated with the clinicopathological factors and prognosis of patients with CRC. Firstly, the correlation of ILT4 and HLA-G expression was analyzed with various clinicopathological characteristics. ILT4 expression was positively correlated with males and increased lymph node metastasis (Table III; $\mathrm{P}=0.002$ and $\mathrm{P}=0.002$, respectively). Additionally, increased expression of HLA-G was correlated with increased CRC Tumor-Node-Metastasis (TNM) staging $(\mathrm{P}=0.030)$.

According to ILT4 and HLA-G expression levels, patients were divided into 4 groups to further examine the association between ILT4/HLA-G co-expression and various clinicopathological factors. As presented in Table IV, compared with the ILT4-/HLA-G-group, ILT4/HLA-G co-expression in the ILT4+/HLA-G+ group was significantly associated with males $(\mathrm{P}=0.025)$ and increased lymph node metastasis $(\mathrm{P}=0.041)$. Additionally, compared with the ILT4+/HLA-G- group, ILT4/HLA-G co-expression was associated with advanced TNM staging $(\mathrm{P}=0.001)$. Older age $(\mathrm{P}=0.042)$, males $(\mathrm{P}=0.001)$, increased lymph node metastasis $(\mathrm{P}=0.038)$ and advanced TNM staging $(\mathrm{P}=0.030)$ were associated with ILT4/HLA-G co-expression, compared with the ILT4-/HLA-G+ group.

As depicted in Fig. 1D, patients with ILT4+/HLA-G+ had a decreased survival time, compared with the ILT4-/HLA-G$(\mathrm{P}=0.032)$ and ILT4+/HLA-G- ( $\mathrm{P}=0.043)$ groups. However, no significant difference in OS was observed, compared with the ILT4-/HLA-G+ group ( $\mathrm{P}=0.395)$.

Co-expression of ILT4 and HLA-G is also detected in CRC cells. The expression levels of ILT4 and HLA-G were examined in FHC and CRC cells (HCT1116, HT29, SW480 and SW620 cells) by western blotting (Fig. 2A) and RT-qPCR (Fig. 2B and 2C). CRC cells exhibited increased levels of ILT4 and HLA-G expression, compared with normal cells. Additionally, increased levels of ILT4 and HLA-G were detected in HCT116 cells, and reduced levels in HT29 cells, indicating that the proteins ILT4 and HLA-G may be co-expressed in CRC cells.

Interference of ILT4 expression affects the levels of HLA-G and regulates $C R C$ cell proliferation, invasion and migration. To investigate the regulatory effects of ILT4 on the expression of HLA-G in CRC cells, ILT4 was overexpressed in HT29 and SW480 cells via an ILT4 plasmid (ILT4-vector), and ILT4 expression was inhibited in HCT116 and SW620 cells via ILT4 shRNA (shILT-4). Western blotting and RT-qPCR assays were performed to examine HLA-G expression. The overexpression of ILT4 in HT29 (Fig. 3A and B) and SW480 cells (Fig. 3C and D) upregulated the expression of HLA-G.

Simultaneously, the present study assessed whether ILT4 influenced CRC cell proliferation, migration and invasion. The results demonstrated that ILT4-overexpressing HT29 and SW480 cells had a notably increased capacity for proliferation, migration and invasion, compared with the negative control (Fig. 4).

Similarly, HLA-G expression was notably downregulated when ILT4 expression was reduced in HCT116 (Fig. 5A and B) and SW620 cells (Fig. 5C and D). Additionally, downregulation of ILT4 notably reduced the proliferation, migration and invasion of HCT116 and SW620 cells (Fig. 6). These results indicated that ILT4 promotes an increased proliferative, migratory and invasive phenotype in CRC cells.

HLA-G fusion protein upregulates the ILT4 level in CRC cells in a dose-dependent manner. The effects of HLA-G expression on ILT4 expression were assessed in CRC cell lines. HT29 cells, which express a low level of ILT4/HLA-G, were treated with different concentrations $(10,20,50,100$, 200 and $500 \mathrm{ng} / \mathrm{ml}$ ) of HLA-G fusion protein. In the range of $10-200 \mathrm{ng} / \mathrm{ml}$ concentration, HLA-G fusion protein notably upregulated the expression of ILT4 at the mRNA and protein levels in a dose-dependent manner (Fig. 7).

HLA-G fusion protein induces the activation of AKT and ERK protein and promotes the proliferation, migration and 

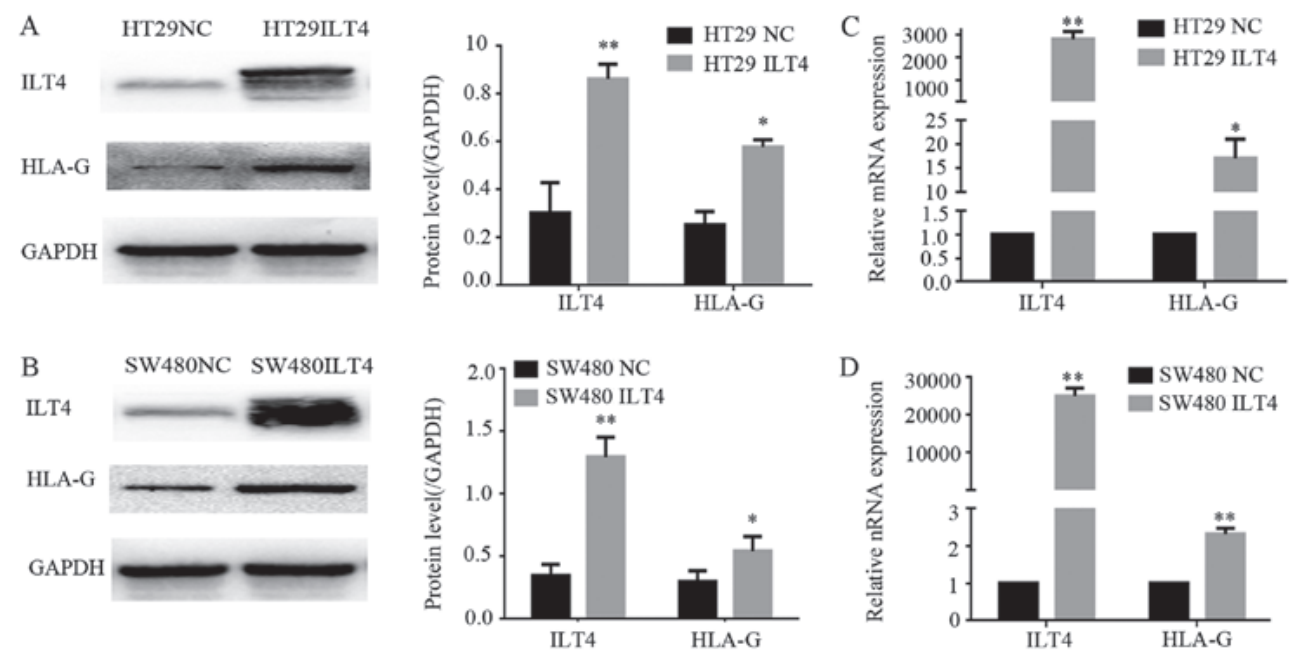

Figure 3. Upregulation of ILT4 induces HLA-G expression. In HT29 cells, when ILT4 expression was overexpressed, HLA-G expression was increased at the (A) protein level and (B) mRNA level. In SW480 cells, when ILT4 expression was overexpressed, HLA-G expression was increased at the (C) protein level and (D) mRNA level. ${ }^{*} \mathrm{P}<0.05$ and ${ }^{* *} \mathrm{P}<0.01$ vs. the corresponding NC. The results are presented as the mean \pm standard deviation from three independent experiments. CRC, colorectal cancer; HLA-G, human leukocyte antigen-G; ILT4, immunoglobulin-like transcript 4; NC, negative control.
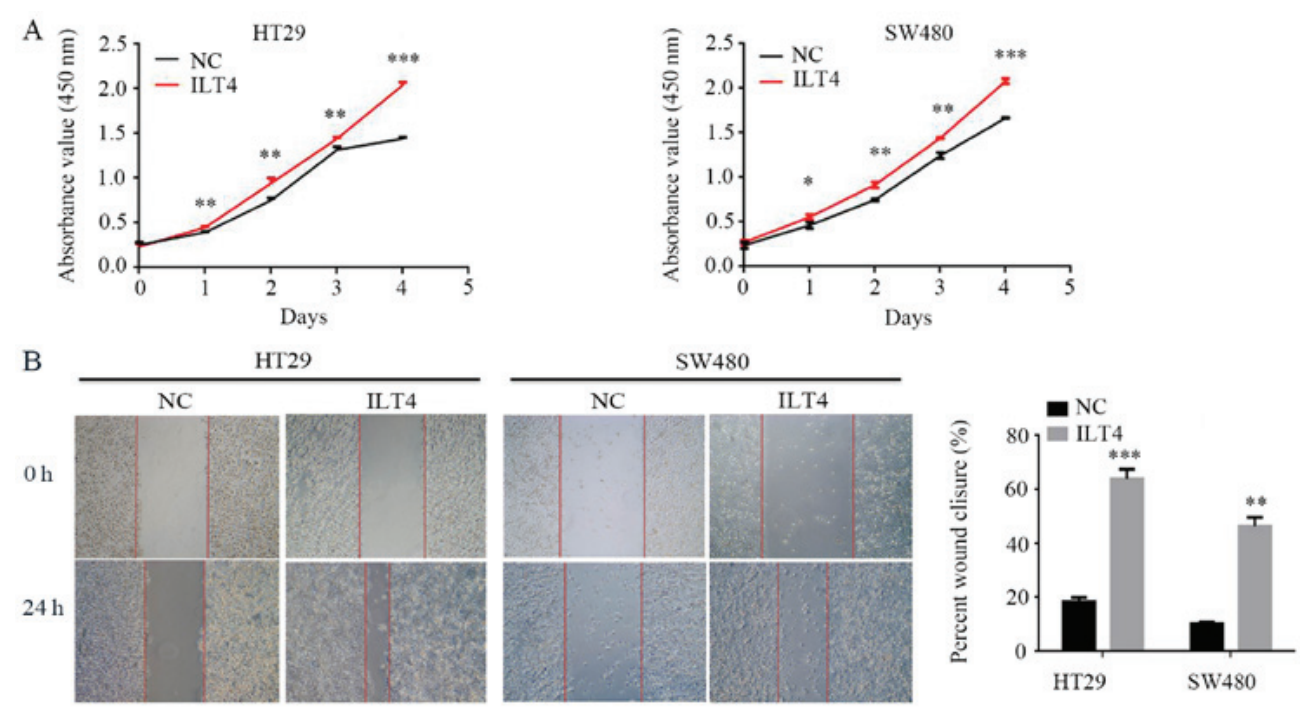

C
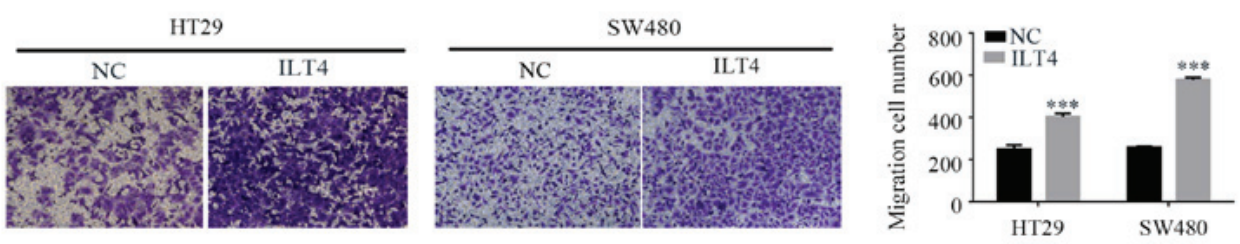

D
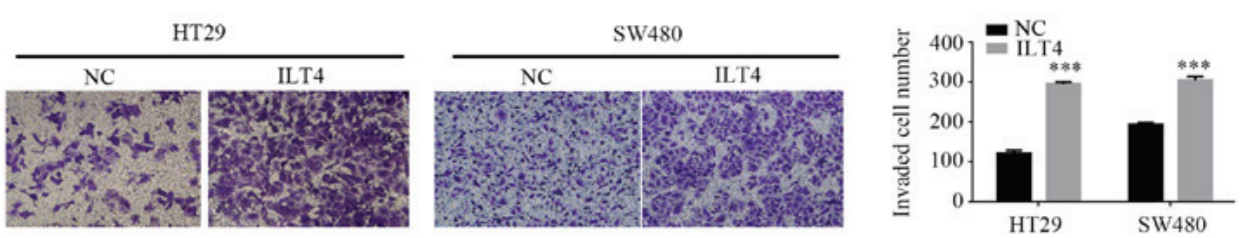

Figure 4. Upregulation of ILT4/HLA-G expression promotes the proliferation, migration and invasion of CRC cells. (A) Effects of ILT4/HLA-G overexpression on proliferation were evaluated by Cell Counting Kit-8 assays. The effects of ILT4/HLA-G overexpression on migration were investigated by (B) wound-healing assay (magnification, $\mathrm{x} 40$ ) and (C) Transwell migration assay (magnification, x100) (D) The effects of ILT4/HLA-G overexpression on invasion were measured by Matrigel invasion assays. Magnification, $x 100 .{ }^{*} \mathrm{P}<0.05,{ }^{* *} \mathrm{P}<0.01$ and ${ }^{* * *} \mathrm{P}<0.001 \mathrm{vs}$. the corresponding NC. The results are presented as the mean \pm standard deviation from three independent experiments. HLA-G, human leukocyte antigen-G; ILT4, immunoglobulin-like transcript 4; NC, negative control.

invasion of CRC cells through binding with ILT4. To identify the underlying molecular mechanisms of ILT4/HLA-G in CRC progression, HT29 cells were treated with $200 \mathrm{ng} / \mathrm{ml}$
HLA-G fusion protein, and the expression levels of ERK1/2 and AKT were analyzed. The results demonstrated that the levels of phospho-ERK1/2 and phospho-AKT were notably 

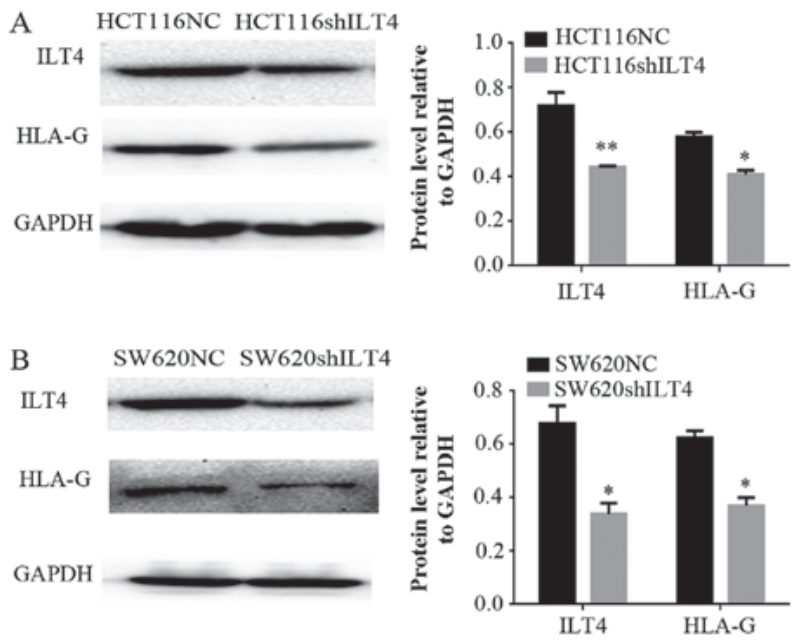
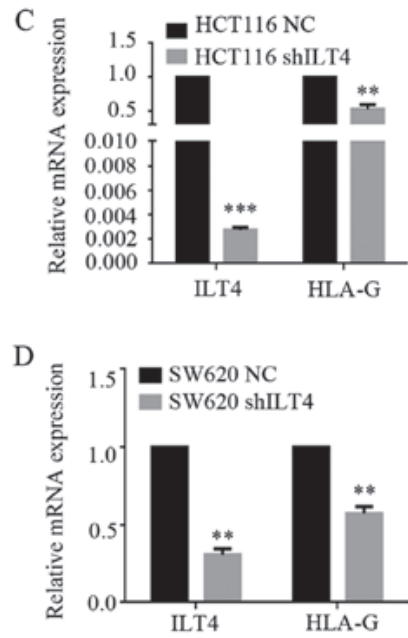

Figure 5. Downregulation of ILT4 inhibits HLA-G expression. In HCT116 cells, when ILT4 expression was inhibited, HLA-G expression was decreased at the (A) protein level and (B) mRNA level. In SW620 cells, when ILT4 expression was overexpressed, HLA-G expression was increased at the (C) protein level and (D) mRNA level. ${ }^{*} \mathrm{P}<0.05,{ }^{* *} \mathrm{P}<0.01$ and ${ }^{* * *} \mathrm{P}<0.001 \mathrm{vs}$. the corresponding NC. The results are presented as the mean \pm standard deviation from three independent experiments. HLA-G, human leukocyte antigen-G; ILT4, immunoglobulin-like transcript 4; NC, negative control; sh, short hairpin.
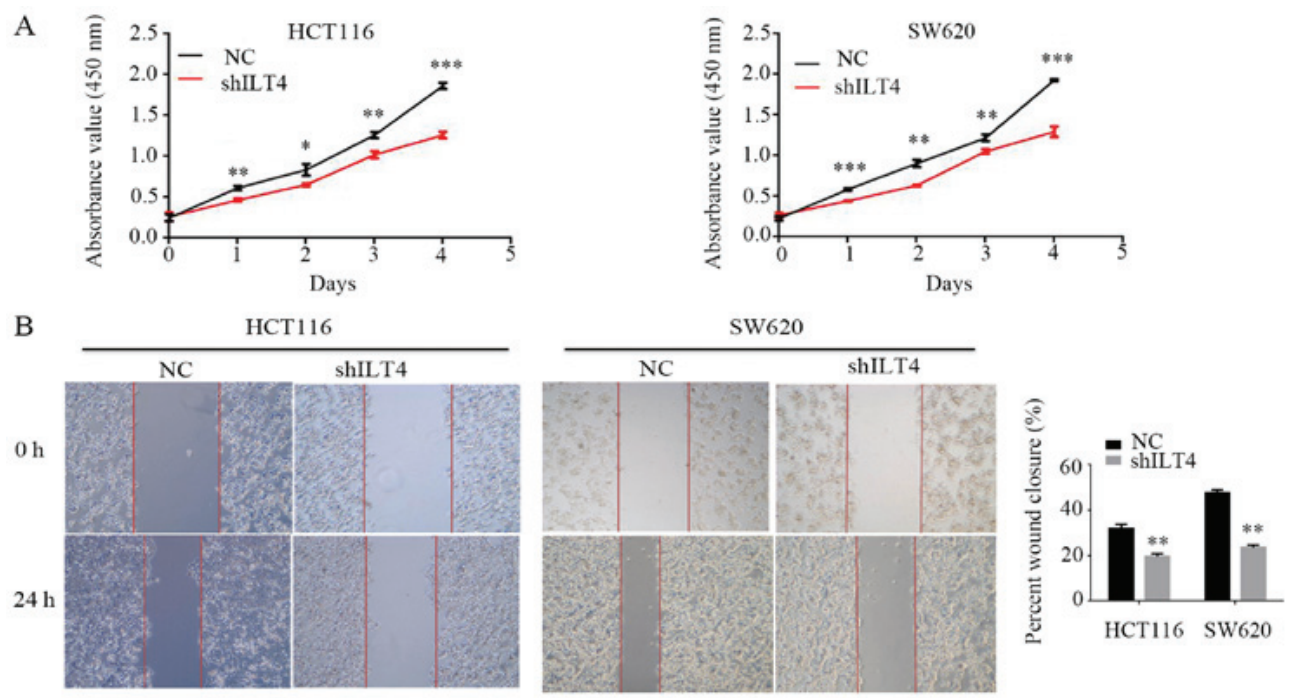

C
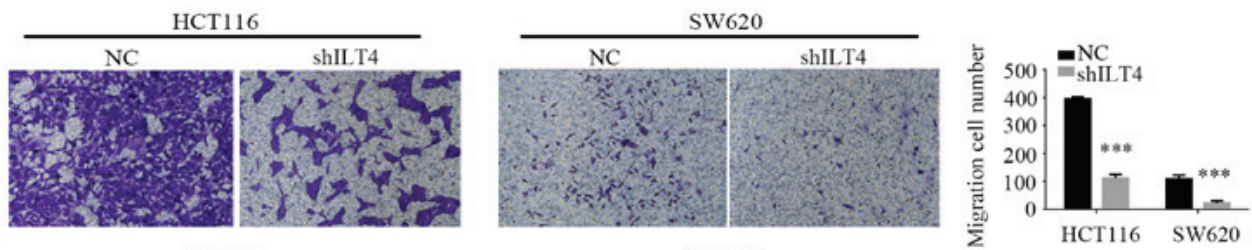

D HCT116
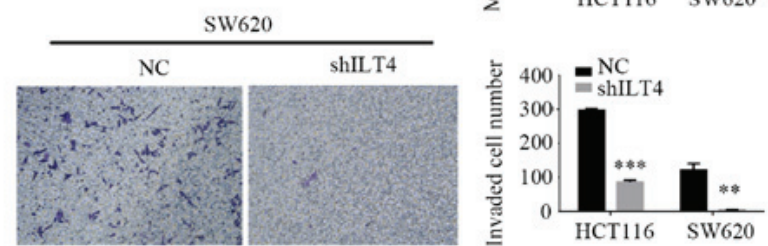

Figure 6. Downregulation of ILT4/HLA-G expression inhibits the proliferation, migration and invasion of CRC cells. (A) The effects of ILT4/HLA-G knockdown on proliferation were evaluated by Cell Counting Kit-8 assays. The effects of ILT4/HLA-G knockdown on migration were investigated by (B) wound-healing assay (magnification, $x 40$ ) and (C) Transwell migration assay (magnification, x100). (D) The effects of ILT4/HLA-G knockdown on invasion were measured by Matrigel invasion assays. Magnification, $x 100 .{ }^{*} \mathrm{P}<0.05,{ }^{* * *} \mathrm{P}<0.01$ and ${ }^{* * * *} \mathrm{P}<0.001$ vs. the corresponding NC. The results are presented as the mean \pm standard deviation from three independent experiments. HLA-G, human leukocyte antigen-G; ILT4, immunoglobulin-like transcript 4; NC, negative control; sh, short hairpin.

enhanced, while the total ERK and AKT levels did not change significantly (Fig. 8A). Simultaneously, following stimulation by HLA-G, HT29 cells exhibited an increased capacity for proliferation, migration and invasion (Fig. 8B-E). 

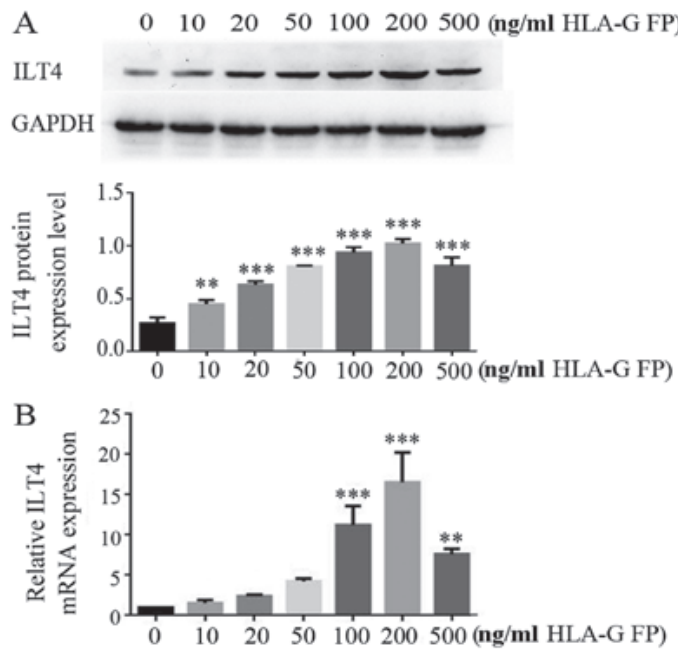

Figure 7. HLA-G FP upregulates ILT4 expression in CRC cells in a dose-dependent manner. (A) Protein expression of ILT4 in HT29 cells following adding different concentrations $(10,20,50,100,200$ and $500 \mathrm{ng} / \mathrm{ml}$ ) of HLA-G FP was increased, compared with cells with $0 \mathrm{ng} / \mathrm{ml}$ HLA-G FP. (B) The expression of ILT4 mRNA in HT29 cells following adding different concentrations (10, 20, 50, 100, 200 and $500 \mathrm{ng} / \mathrm{ml})$ of HLA-G FP was increased, compared with cells with $0 \mathrm{ng} / \mathrm{ml}$ HLA-G FP. The results are presented as the mean \pm standard deviation from three independent experiments. ${ }^{* *} \mathrm{P}<0.01$ and ${ }^{* * * *} \mathrm{P}<0.001 \mathrm{vs}$. cells with $0 \mathrm{ng} / \mathrm{ml}$ HLA-G FP. HLA-G, human leukocyte antigen-G; ILT4, immunoglobulin-like transcript 4; FP, fusion protein.
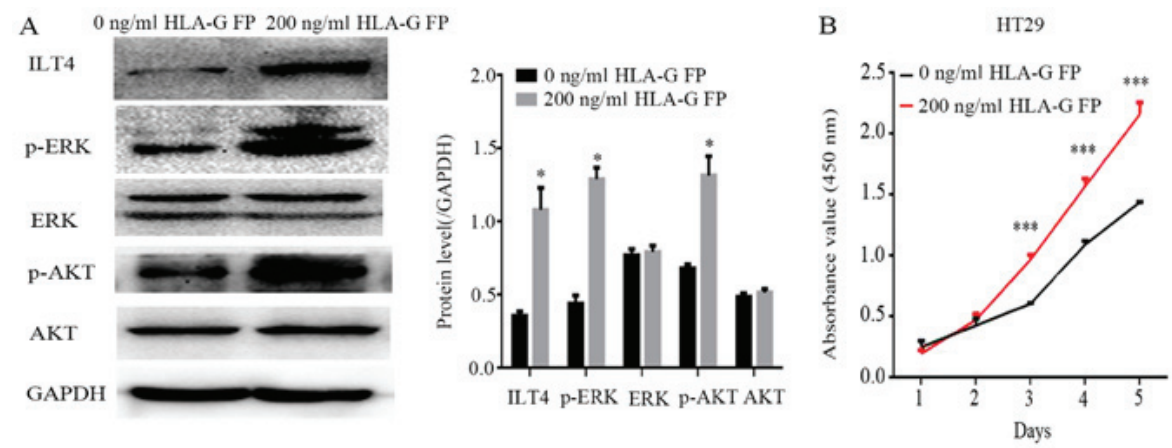

C
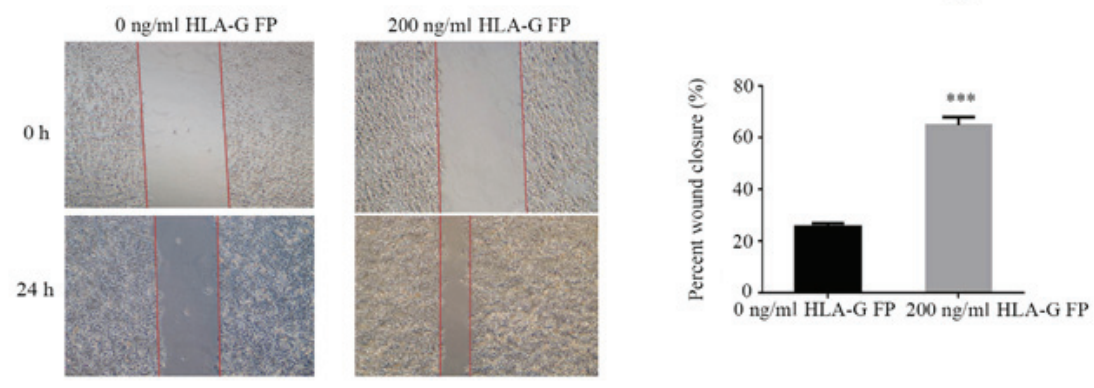

D

$0 \mathrm{ng} / \mathrm{ml}$ HLA-G FP
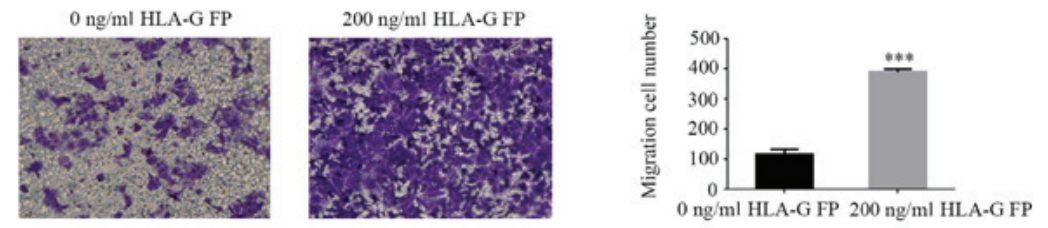

E
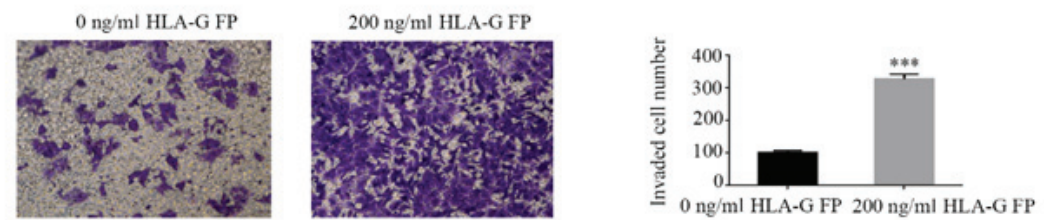

Figure 8. Addition of HLA-G FP activates AKT and ERK signaling, and promotes the proliferation, migration and invasion of HT29 cells. (A) Protein expression of ILT4, AKT, p-AKT, ERK, p-ERK and GAPDH in HT29 following the addition of HLA-G FP. PBS served as a negative control. (B) The effects of HLA-G FP on proliferation were evaluated by Cell Counting Kit- 8 assays. The effects of HLA-G FP on migration were detected by (C) wound-healing assay (magnification, $\mathrm{x} 40$ ) and (D) Matrigel invasion assay (magnification, x100). (E) The effects of HLA-G FP on invasion were measured by Matrigel invasion assays. Magnification, $\mathrm{x} 100$. The results are presented as the mean \pm standard deviation from three independent experiments. "P<0.05 and ${ }^{* * * *} \mathrm{P}<0.001$ vs. cells with $0 \mathrm{ng} / \mathrm{ml}$ HLA-G FP. HLA-G, human leukocyte antigen-G; ILT4, immunoglobulin-like transcript 4; FP, fusion protein; p-, phospho-; ERK, extracellular signal-regulated kinase; AKT, protein kinase B. 

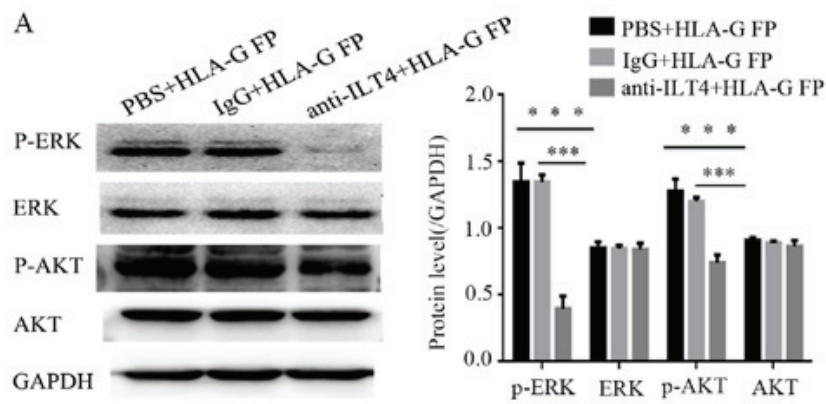

C

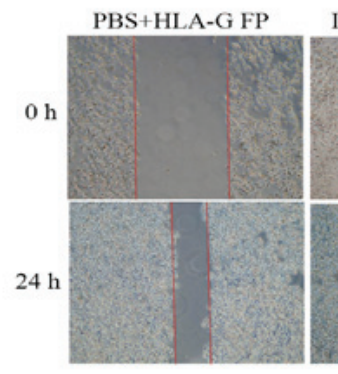

D

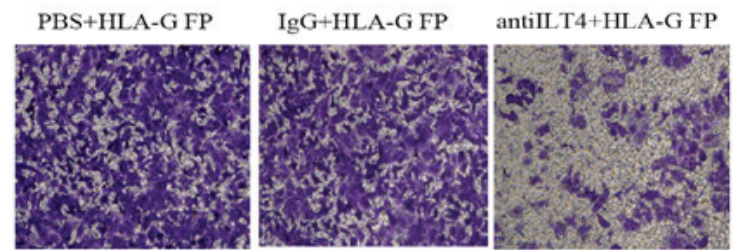

$\mathrm{E}$

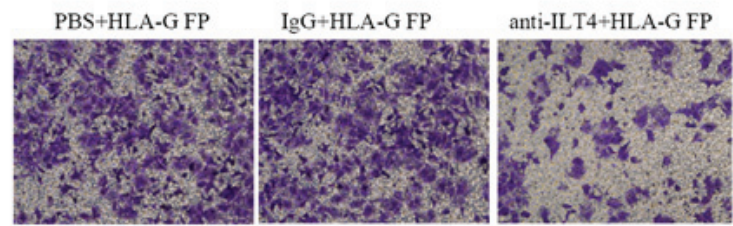

IgG+HLA-G FP antilLT4+HLA-G FP

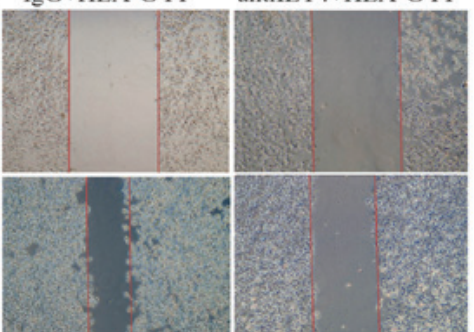

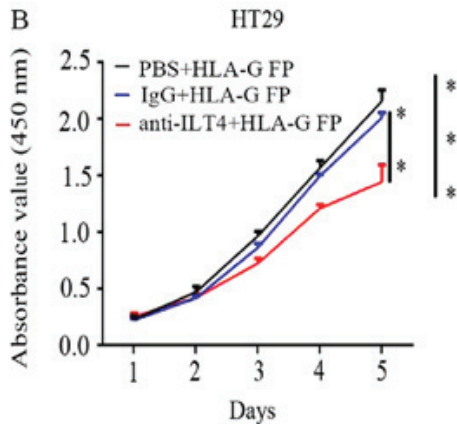
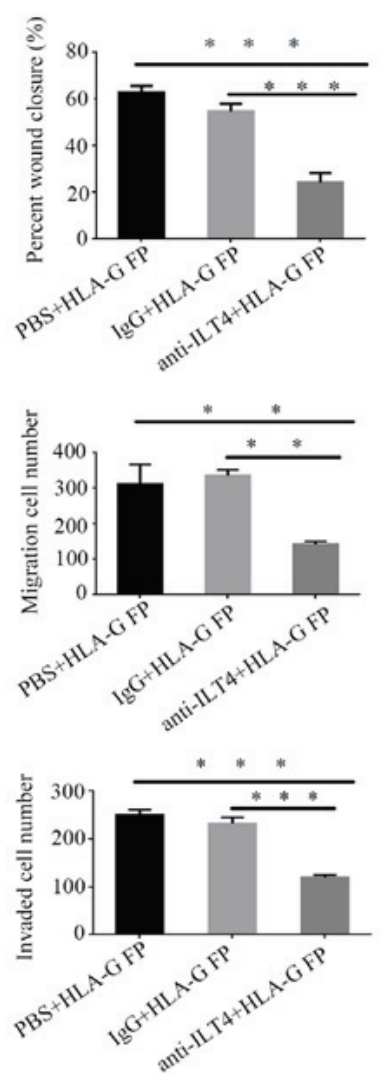

Figure 9. Anti-ILT4 antibody can reduce the signal activation and malignant cellular behaviors promoted by HLA-G. (A) The protein expression of AKT, p-AKT, ERK, p-ERK and GAPDH in HT29 cells following treatment with anti-ILT4 antibody and HLA-G FP. (B) Following blocking ILT4, the effects of HLA-G FP on proliferation were evaluated by Cell Counting Kit-8 assays, the effects on migration were measured by (C) wound-healing assay (magnification, $\mathrm{x} 40$ ) and (D) Transwell migration assay (magnification, $\mathrm{x} 100$ ), and the effects on invasion were measured by (E) Matrigel invasion assays (magnification, $\mathrm{x} 100)$. The same volume of IgG and PBS were used as negative controls. The results are presented as the mean \pm standard deviation from three independent experiments. ${ }^{* *} \mathrm{P}<0.01$ and ${ }^{* * *} \mathrm{P}<0.001$ vs. cells with PBS+HLA-G FP. HLA-G, human leukocyte antigen-G; ILT4, immunoglobulin-like transcript 4; FP, fusion protein; p-, phospho-; ERK, extracellular signal-regulated kinase; AKT, protein kinase B.

The present study sought to block the ILT4 expression in HT29 cells via anti-ILT4 antibody to identify its function in the cellular malignant behaviors promoted by HLA-G. Notably, the upregulation of phospho-ERK1/2 and phospho-AKT expression induced by HLA-G was no longer significantly altered (Fig. 9A), and the cell proliferation, invasion and migration of HT29 were notably reduced (Fig. 9B-E).

\section{Discussion}

ILT4 is a predominantly immunosuppressive molecule and the majority of researchers have focused on its function on DCs (23-26). Our previous studies identified ILT4 overexpression in breast cancer and NSCLC tissues (9-11). However, the expression level of ILT4 in human CRCs and its underlying role in CRC tumorigenesis have not been reported. HLA-G has been reported to be able to upregulate the expression of ILT2, ILT3 and ILT4 in antigen-presenting cells (13), and our previous study demonstrated the interaction of HLA-G with ILT4 in NSCLC (11). Previously, researchers have investigated the HLA-G/ILT interaction as an immune checkpoint, and it has been deduced that the use of anti-HLA-G or anti-ILT antibodies may be considered as a novel immunotherapy strategy $(16,26-28)$. Studies have also detected the expression of HLA-G in CRC, but its associated mechanisms remain to be investigated $(29,30)$.

The present study demonstrated the high expression of ILT4 and HLA-G in human CRC tissues, and the co-expression of the two proteins was associated with the pathological characteristics (age, sex, lymph node metastasis 
and TNM staging) and survival time of patients with CRC. Furthermore, the expression of ILT4 in men is increased, compared with women. Compared with other groups, patients with CRC in the ILT4+/HLA-G+ group had larger tumor sizes, increased TNM stages, increased lymph node metastasis and reduced survival times, which indicated that ILT4 and HLA-G could be prognostic factors to predict poor clinical response and survival time in patients with CRC. A number of studies analyzed the association between HLA-G and the OS of patients with CRC, but have not reported consistent conclusions $(29,31)$. The present data, analyzed by Kaplan-Meier, demonstrated that the high expression of HLA-G and ILT4 was statistically associated with the survival time of patients with CRC.

Additionally, the expression of ILT4/HLA-G and their interaction in CRC cell lines were detected, at the mRNA and protein levels. The interference of ILT4 expression was positively associated with HLA-G expression; however, the administration of HLA-G fusion protein increased the expression of ILT4 in a dose-dependent manner. The present study confirmed that the interaction between ILT4/HLA-G in CRC cells may be mediated in an autocrine manner, which has been demonstrated in NSCLC (11). Furthermore, it was elucidated that the ILT4/HLA-G interaction notably enhanced cell proliferation, migration and invasion, which confirmed the potential of ILT4/HLA-G overexpression as a tumor indicator. Additionally, the present study sought to reveal the underlying molecular mechanism of ILT4/HLA-G in tumor promotion. It was demonstrated that HLA-G induced the activation of AKT and ERK1/2 signaling by binding with ILT4, accounting for the promoted cell proliferation, invasion and migration of HT29 cells.

In conclusion, the present study identified the ILT4 and HLA-G overexpression in CRC tissue samples and its association with poor prognosis in patients with CRC. Furthermore, it was demonstrated that the ILT4/HLA-G interaction facilitated the cell proliferation, invasion and migration of CRC by activating AKT and ERK signaling. Therefore, it may be considered that ILT4-HLA-G may function as a beneficial checkpoint in the prevention and treatment of CRC. Further research is necessary to provide in vivo data and determine other factors involved in ILT4/HLA-G signaling.

\section{Acknowledgements}

Not applicable.

\section{Funding}

The present study was supported by the National Natural Science Foundation of China (grant no. 81372334), the Natural Science Foundation of Shandong Province (grant no. ZR2010HM105) and the Clinical Medical Innovation Project of Jinan City (grant no. 201805064).

\section{Availability of data and materials}

All data generated or analyzed during this study are included in this published article.

\section{Authors' contributions}

ZC, LW and YH performed the cell experiments and wrote this original manuscript. WG and $\mathrm{XW}$ analyzed the clinical data and collected the human CRC tissue samples. RG and MZ performed the statistical analysis. YS and SY designed the research and modified the manuscript. All authors read the final manuscript and approved the publication.

\section{Ethics approval and consent to participate}

This study was approved by the Ethics Committee of Jinan Central Hospital Affiliated to Shandong University (Jinan, China) and written informed consent was obtained from all patients.

\section{Patient consent for publication}

All patients involved in this study gave consent for the publication of the clinical and pathological data.

\section{Competing interests}

The authors declare that they have no competing interests.

\section{References}

1. Liang R, Lin Y, Yuan CL, Liu ZH, Li YQ, Luo XL, Ye JZ and Ye HH: High expression of estrogen-related receptor $\alpha$ is significantly associated with poor prognosis in patients with colorectal cancer. Oncol Lett 15: 5933-5939, 2018.

2. Ferlay J, Soerjomataram I, Dikshit R, Eser S, Mathers C, Rebelo M, Parkin DM, Forman D and Bray F: Cancer incidence and mortality worldwide: Sources, methods and major patterns in GLOBOCAN 2012. Int J Cancer 136: E359-E386, 2015.

3. Petera J, Dušek L, Sirák I, Soumarova R and Jarkovsky J: Cancer in the elderly in the Czech Republic. Eur J Cancer Care (Engl) 24: 163-178, 2015.

4. Pitule P, Vycital O, Bruha J, Novak P, Hosek P, Treska V, Hlavata I, Soucek P, Kralickova M and Liska V: Differential expression and prognostic role of selected genes in colorectal cancer patients. Anticancer Res 33: 4855-4865, 2013.

5. Colonna M, Nakajima $\mathrm{H}$ and Cella $\mathrm{M}$ : A family of inhibitory and activating Ig-like receptors that modulate function of lymphoid and myeloid cells. Semin Immunol 12: 121-127, 2000.

6. Borges L and Cosman D: LIRs/ILTs/MIRs, inhibitory and stimulatory Ig-superfamily receptors expressed in myeloid and lymphoid cells. Cytokine Growth Factor Rev 11: 209-217, 2000 .

7. Shiroishi M, Tsumoto K, Amano K, Shirakihara Y, Colonna M, Braud VM, Allan DS, Makadzange A, Rowland-Jones S, Willcox B, et al: Human inhibitory receptors Ig-like transcript 2 (ILT2) and ILT4 compete with CD8 for MHC class I binding and bind preferentially to HLA-G. Proc Natl Acad Sci USA 100: 8856-8861, 2003.

8. Nakajima H, Asai A, Okada A, Ping L, Hamajima F, Sata T and Isobe K: Transcriptional regulation of ILT family receptors. J Immunol 171: 6611-6620, 2003.

9. Sun Y, Liu J, Gao P, Wang Y and Liu C: Expression of Ig-like transcript 4 inhibitory receptor in human non-small cell lung cancer. Chest 134: 783-788, 2008.

10. Liu J, Wang L, Gao W, Li L, Cui X, Yang H, Lin W, Dang Q, Zhang $N$ and Sun Y: Inhibitory receptor immunoglobulin-like transcript 4 was highly expressed in primary ductal and lobular breast cancer and significantly correlated with IL-10. Diagn Pathol 9: 85, 2014.

11. Zhang Y, Zhao J, Qiu L, Zhang P, Li J, Yang D, Wei X, Han Y, Nie S and Sun Y: Co-expression of ILT4/HLA-G in human non-small cell lung cancer correlates with poor prognosis and ILT4-HLA-G interaction activates ERK signaling. Tumour Biol 37: 11187-11198, 2016. 
12. Djurisic S and Hviid TV: HLA Class Ib Molecules and Immune Cells in Pregnancy and Preeclampsia. Front Immunol 5: 652, 2014.

13. LeMaoult J, Zafaranloo K, Le Danff C and Carosella ED: HLA-G up-regulates ILT2, ILT3, ILT4, and KIR2DL4 in antigen presenting cells, NK cells, and T cells. FASEB J 19: 662-664, 2005.

14. Köstlin N, Ostermeir AL, Spring B, Schwarz J, Marmé A, Walter CB, Poets CF and Gille C: HLA-G promotes myeloid-derived suppressor cell accumulation and suppressive activity during human pregnancy through engagement of the receptor ILT4. Eur J Immunol 47: 374-384, 2017.

15. Rouas-Freiss N, Moreau P, LeMaoult J and Carosella ED: The dual role of HLA-G in cancer. J Immunol Res 2014: 359748, 2014

16. Rouas-Freiss N, LeMaoult J, Verine J, Tronik-Le Roux D, Culine S, Hennequin C, Desgrandchamps F and Carosella ED Intratumor heterogeneity of immune checkpoints in primary renal cell cancer: Focus on HLA-G/ILT2/ILT4. OncoImmunology 6: e1342023, 2017

17. Özgül Özdemir RB, Özdemir AT, Oltulu F, Kurt K, Yiğittürk G and Kirmaz C: A comparison of cancer stem cell markers and nonclassical major histocompatibility complex antigens in colorectal tumor and noncancerous tissues. Ann Diagn Pathol 25: 60-63, 2016.

18. Alaoui L, Palomino G, Zurawski S, Zurawski G, Coindre S, Dereuddre-Bosquet N, Lecuroux C, Goujard C, Vaslin B, Bourgeois C, et al: Early SIV and HIV infection promotes the LILRB2/MHC-I inhibitory axis in cDCs. Cell Mol Life Sci 75: 1871-1887, 2018.

19. Nowak I, Wilczyńska K, Wilczyński JR, Malinowski A Radwan P, Radwan M and Kuśnierczyk P: KIR, LILRB and their Ligands' Genes as Potential Biomarkers in Recurrent Implantation Failure. Arch Immunol Ther Exp (Warsz) 65: 391-399, 2017.

20. Guerra-de Blas PC, Villaseñor-Talavera YS, Cruz-González DJ, Baranda L, Doníz-Padilla L, Abud-Mendoza C, González-Amaro R and Monsiváis-Urenda AE: Analysis of the Expression and Function of Immunoglobulin-Like Transcript 4 (ILT4, LILRB2) in Dendritic Cells from Patients with Systemic Lupus Erythematosus. J Immunol Res 2016: 4163094, 2016.

21. Edge SB and Compton CC: The American Joint Committee on Cancer: The 7th edition of the AJCC cancer staging manual and the future of TNM. Ann Surg Oncol 17: 1471-1474, 2010.
22. Livak KJ and Schmittgen TD: Analysis of relative gene expression data using real-time quantitative PCR and the 2(-Delta Delta C(T)) method. Methods 25: 402-408, 2001.

23. Gao A, Sun Y and Peng G: ILT4 functions as a potential checkpoint molecule for tumor immunotherapy. Biochim Biophys Acta Rev Cancer 1869: 278-285, 2018.

24. Castellaneta A, Mazariegos GV, Nayyar N, Zeevi A and Thomson AW: HLA-G level on monocytoid dendritic cells correlates with regulatory T-cell Foxp3 expression in liver transplant tolerance. Transplantation 91: 1132-1140, 2011.

25. Liang S, Ristich V, Arase H, Dausset J, Carosella ED and Horuzsko A: Modulation of dendritic cell differentiation by HLA-G and ILT4 requires the IL-6 - STAT3 signaling pathway. Proc Natl Acad Sci USA 105: 8357-8362, 2008.

26. Ristich V, Zhang W, Liang S and Horuzsko A: Mechanisms of prolongation of allograft survival by HLA-G/ILT4-modified dendritic cells. Hum Immunol 68: 264-271, 2007.

27. Carosella ED, Rouas-Freiss N, Tronik-Le Roux D, Moreau P and LeMaoult J: HLA-G: An Immune Checkpoint Molecule. Adv Immunol 127: 33-144, 2015.

28. Apps R, Gardner L and Moffett A: A critical look at HLA-G. Trends Immunol 29: 313-321, 2008.

29. Zeestraten EC, Reimers MS, Saadatmand S, Goossens-Beumer IJ, Dekker JW, Liefers GJ, van den Elsen PJ, van de Velde CJ and Kuppen PJ: Combined analysis of HLA class I, HLA-E and HLA-G predicts prognosis in colon cancer patients. Br J Cancer 110: 459-468, 2014.

30. Guo ZY, Lv YG, Wang L, Shi SJ, Yang F, Zheng GX, Wen WH and Yang AG: Predictive value of HLA-G and HLA-E in the prognosis of colorectal cancer patients. Cell Immunol 293: 10-16, 2015.

31. Reimers MS, Engels CC, Putter H, Morreau H, Liefers GJ, van de Velde CJ and Kuppen PJ: Prognostic value of HLA class I, HLA-E, HLA-G and Tregs in rectal cancer: A retrospective cohort study. BMC Cancer 14: 486, 2014.

This work is licensed under a Creative Commons Attribution-NonCommercial-NoDerivatives 4.0 International (CC BY-NC-ND 4.0) License. 